\title{
Lekcje odwagi a pokusa milczenia
}

\author{
Lessons of Courage and the Temptation of Silence
}

\author{
Krzysztof Koc
Uniwersytet im. Adama Mickiewicza w Poznaniu
ORCID:0000-0001-9734-945X
}

\begin{abstract}
The article talks about the need to rethink the way of talking about Polish-Jewish relations in the context of the Holocaust at school. The analysis of the new non-fictional texts presenting the fate of Jews in occupied Poland and the attitude of Poles to these dramatic events in the past and today, by Anna Bikont, Mirosław Tryczyk and Marcin Kącki, prompts us to reflect on the purposefulness of such reflection and the way of its implementation. The concept of existential reading proposed in the article, serving to shape civic skepticism towards a narrative that avoids difficult and concealed topics, seems to be a valuable lesson of courage, needed to deal with xenophobia, discrimination and hate speech in the contemporary world.
\end{abstract}

Key words: Poles, Jews, Holocaust, silence, education, citizenship

Streszczenie: Artykuł opowiada o potrzebie przemyślenia na nowo sposobu opowiadania w szkole o relacjach polsko-żydowskich w kontekście Zagłady. Analiza nowych tekstów niefikcjonalnych przybliżających los Żydów w okupowanej Polsce oraz stosunek Polaków do tych dramatycznych wydarzeń, dawniej i dziś, autorstwa Anny Bikont, Mirosława Tryczyka oraz Marcina Kąckiego skłania do zastanowienia nad celowością takiej refleksji i sposobem jej urzeczywistniania. Zaproponowana w artykule koncepcja czytania egzystencjalnego, służąca kształtowaniu obywatelskiego sceptycyzmu wobec narracji omijającej tematy trudne i przemilczane, wydaje się cenną lekcją odwagi, potrzebną, by zmierzyć się z ksenofobią, dyskryminacją i językiem nienawiści we współczesnym świecie.

Słowa kluczowe: Polacy, Żydzi, Zagłada, przemilczenia, edukacja, obywatelskość

\section{Jak mówić, by nie mówić - o relacjach polsko-żydowskich w edukacji}

Zanim spróbujemy wydobyć potencjał edukacyjny z wydanych w ostatnich latach tekstów opisujących stosunek Polaków do Żydów (w kontekście strasznego doświadczenia, jakim była Zagłada), warto przyjrzeć się uważnie uwarunkowaniom, w jakich dzisiaj przychodzi podejmować namysł nad tym trudnym tematem. Analiza podstawy programowej obowiązującej w szkole 
podstawowej (z 2017 roku) i w liceum (z 2018 roku) skłania do wniosku, że zarówno zagadnienia związane $\mathrm{z}$ Holokaustem, jak i dotyczące $\mathrm{w}$ tym kontekście relacji polsko-żydowskich, nie są szczególnie wyeksponowane czy dowartościowane ${ }^{1}$. Cztery konkretne teksty poruszające doświadczenie Zagłady zaproponowano jako lekturę w liceum (dwa opowiadania Tadeusza Borowskiego Prosze państwa do gazu i Ludzie, którzy szli, Hanny Krall Zdą̇yć przed Panem Bogiem i opowiadanie Zofii Nałkowskiej Przy torze kolejowym; to ostatnie wskazano jako lekturę uzupełniającą ${ }^{2}$ ), natomiast ani jednego w szkole podstawowej ${ }^{3}$. Wybrano zatem utwory wymagające od nauczyciela oraz od ucznia naprawdę wysokich kompetencji odbiorczych, bardzo dojrzałej świadomości historycznej, a także rozbudowanej obudowy kontekstowej, z jednej strony przybliżającej historyczność Holokaustu, a $\mathrm{z}$ drugiej uniwersalizującej tę tragedię i ukazującej jej przełomowy wpływ na sposób myślenia o religii, etyce, filozofii, prawie, języku, kulturze. Żadnego nauczyciela języka polskiego nie trzeba również przekonywać, że zarówno opowieść Marka Edelmana, zrelacjonowana przez Hannę Krall, jak i opowiadania Borowskiego wystawiają na próbę dotychczasowe etyczne pewniki. Z kolei autorzy artykułów opublikowanych w tomie Zagłada w „Medalionach” Zofii Nałkowskiej. Teksty i konteksty, analizując opowiadanie Przy torze kolejowym, zwracają uwage na eksponowany w nim konflikt między pragnieniem przynależności do wspólnoty a imperatywem działania na rzecz cierpiącego. Stwierdzają, iż Medaliony opowiadają przede wszystkim o wrogości Polaków wobec Żydów, a nie o niechęci niesienia im pomocy, o tym, co się dzieje, gdy indywidualny wybór moralny zostanie zastąpiony wyborem kolektywnym. Badacze uzasadniają również przekonująco, iż te krótkie utwory dowodzą, że bierność wobec krzywdy drugiego człowieka jest postawą zaangażowaną, a nie aksjologicznie neutralną. Podstawa programowa zawiera zatem szczelinę, przez którą przynajmniej w szkole ponadpodstawowej można przyjrzeć się bardzo niepokojącym kwestiom, a zwłaszcza przemilczeniom, jakie towarzyszą namysłowi nad postawą Polaków wobec Żydów. Nie jest i nie będzie to jednak zadanie metodycznie łatwe.

\footnotetext{
${ }^{1}$ O problemach z utworzeniem kanonu tekstów na temat Zagłady i ich przyczynach pisze w swojej monografii Sylwia Karolak (zob. Karolak 2014).

${ }^{2}$ Oczywiście, w szkole ponadpodstawowej istnieje też możliwość wprowadzania tekstów poetyckich na ten temat, gdyż to nauczyciel decyduje, które wiersze - na przykład Różewicza czy Miłosza - będzie z uczniami interpretował. Teoretycznie w szkole podstawowej również można się tą tematyką zająć, korzystając z zapisu pozwalającego nauczycielowi zaproponować do lektury teksty spoza spisu umieszczonego w podstawie programowej. Trudno jednak ocenić, czy i jak z tej opcji korzystają.

${ }^{3}$ Budzi to zdziwienie, gdyż literatura dziecięca i młodzieżowa tego trudnego tematu nie tylko nie omija, ale przybliża go w bardzo zróżnicowany i ciekawy sposób; zob: np. Wójcik-Dudek M., 2016,

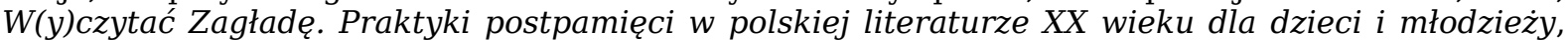
Katowice; por. też: Kuczyńska-Koschany K., 2020, Literatura (p)o Zagładzie. Notatki do opolskiego wykładu (część I), „Indeks. Pismo Uniwersytetu Opolskiego”, nr 3-4 (205-206), s. 97-100; eadem, Literatura (p)o Zagładzie. Notatki do opolskiego wykładu (część II), 2020, „Indeks. Pismo Uniwersytetu Opolskiego", nr 5-6 (207-208), s. 89-93. [Wykład w Opolu opracowany został wyłącznie na podstawie literatury dziecięcej i młodzieżowej].
} 


\section{Sprawy przemilczane jako rdzeń współczesnej edukacji humani- stycznej}

Od czasu ukazania się w 2000 roku Sąsiadów Jana Tomasza Grossa coraz trudniej budować opowieść o wspólnocie narodowej, kierującej się w sytuacji zagrożenia i kryzysu wszelkich norm wyłącznie honorem, empatią i gotowością do bezinteresownej pomocy innym, a szczególnie najbardziej prześladowanym. W dodatku badania naukowe i powstałe $\mathrm{w}$ ich wyniku prace (na przykład Joanny Tokarskiej-Bakir, Jana Grabowskiego, Barbary Engelking czy Jacka Leociaka), poświęcone postawom Polaków wobec Zagłady, taką wspólnotową opowieść demaskują jako fałszywą, fragmentaryczną i zideologizowaną.

Jeśli jednak edukacja humanistyczna ma inspirować dojrzałe myślenie o polskości i obywatelskości, to nie może narzucać współczesnemu młodemu pokoleniu ideologicznego rozumienia przeszłości, uniemożliwiając równocześnie poruszanie kwestii budzących wątpliwości czy milcząc w obliczu niewygodnych pytań, także etycznych. Siła literatury i edukacji tkwi nie w pielęgnowaniu strachu przed tym, co przemilczane, ale w podejmowaniu najtrudniejszych tematów. Lęk przed dojrzałą i krytyczną refleksją nad przeszłością, nawet wynikający z troski o rzekome dobro wspólnoty, które mogłoby być narażone na szwank w wyniku mierzenia się z mrocznymi epizodami z historii, zawsze ma wymiar antyobywatelski.

Konieczna jest dzisiaj zmiana edukacyjnego języka, którym opowiada się o polskości. Życie w wielokulturowym świecie, w którym spotkanie z innością jest doświadczeniem powszechnym, wymaga narracji adekwatnej do współczesnej sytuacji politycznej, kulturowej i społecznej ${ }^{4}$. Dlatego refleksję nad przeszłością i relacjami polsko-żydowskimi warto uczynić integralnym elementem owej narracji. Sięgnięcie po tematy przemilczane pozwoli dostrzec, jak niebezpieczne jest postrzeganie świata i innych ludzi wyłącznie w perspektywie różnic etnicznych czy religijnych, często niezwykle mocno wartościujących i uprzedmiotawiających innych (zwykle stanowiących mniejszość, którą łatwo wskazać i zaatakować). Przyjrzenie się tragicznym skutkom takiego myślenia w perspektywie Zagłady być może w pewnym stopniu zapobiegnie podobnym praktykom w stosunku do współczesnych innych, jakimi są choćby uchodźcy czy migranci. Opinia większości i presja

\footnotetext{
${ }^{4}$ Taki postulat formułuje Agnieszka Kania w książce Lekcje (nie)obecności. Dziedzictwo polsko-żydowskie w edukacji polonistycznej, Kraków 2017. Badaczka jednak bardzo ostrożnie i oględnie wypowiada się na temat konieczności rozmawiania w szkole o przemilczeniach dotyczących relacji polsko-żydowskich podczas II wojny światowej. Wątpliwości budzi też dokonane przez nią przeniesienia strachu, uprzedzeń, traumy, niechęci dorosłych do podejmowania tego trudnego tematu na współczesnych uczniów i przypisywanie im reakcji, których raczej trudno oczekiwać, gdyż dotyczą zagadnienia, które nie jest im szczególnie bliskie (także emocjonalnie). Obawy przed naruszeniem narodowego tabu są widoczne również w dość ogólnikowych postulatach edukacyjnych (np. „Ani gloryfikowanie przeszłości i dokonań przodków, ani generalizowanie opinii o ich niewybaczalnej winie nie jest zatem najlepszą drogą do uformowania krytycznych i poszukujących osobowości. Sprawę należy przedstawić w szerszym kontekście, ponieważ problemy związane z nieprzepracowaniem wydarzeń z II wojny światowej nie są jedynie polską specjalnością" - Kania 2017, 149). Znamienne, że w rozdziale Co i jak pamiętaja Polacy, a o czym pamiętać nie chca nie ma konkretnej propozycji skierowanej do uczniów i nauczycieli sugerującej, jak podejmować ten temat za pośrednictwem tekstów bezpośrednio go dotyczących.
} 
z jej strony może być naprawdę morderczą bronią, o czym należy w szkole mówić jasno.

Edukacja, która nie waha się przed podejmowaniem krytycznej refleksji nad charakterem więzi spajających wspólnotę, w tym przypadku wspólnotę narodową, sprzyja również budowaniu zaufania jako ważnego kapitału społecznego. Nie jest to jednak zaufanie, jakim darzy się grupa przestępcza, gdy podejmuje decyzję o zmowie milczenia, czyniąc swoim zakładnikiem i wrogiem każdego, kto postanowiłby ją złamać. Chodzi o zaufanie do jednej z najistotniejszych społecznie instytucji, czyli szkoły, której zadaniem jest budowanie wiarygodnej i dojrzałej opowieści o człowieku i historii, niepomijającej również tego, co przenosi się w sferę narodowego tabu. Jeśli edukację podporządkuje się transmitowaniu opowieści fałszywej i tendencyjnej, to rezultatem nie będzie wzmocnienie wspólnotowej więzi, ale wychowanie ludzi nieufnych, sceptycznie postrzegających wartość i sens edukacji. A stąd już tylko krok do ukształtowania społeczeństwa bezsilnych, a nie społeczeństwa obywatelskiego (zob. Krastew 2013, 60). Nawet jeśli w wyniku lektury tekstów ukazujących zło wyrządzane Żydom przez Polaków rozpadnie się przekonanie niejednego młodego człowieka o niekwestionowanym bohaterstwie całego polskiego narodu, to z tego właśnie powodu warto zaryzykować. Gotowość do zmiany zdania jest bowiem bardzo niedocenianą wartością prodemokratyczną, szyderczo traktowaną natomiast przez wszelkich fundamentalistów, fanatyków i ideologów. Krastew traktuje tę wartość jako polityczną, ale z powodzeniem można w niej widzieć wartość edukacyjną:

Czy spójność jest ważniejsza dla polityki demokratycznej od gotowości do zmiany stanowiska, gdy na przykład uzyska się nowe informacje albo zaistnieją nowe okoliczności? Wyobraźmy sobie, jak wyglądałby świat, gdyby Woodrow Wilson albo Franklin Delano Roosevelt nie zmienili swych początkowych przekonań, że Stany Zjednoczone powinny trzymać się na uboczu (Krastew 2013, 59).

Przyjrzyjmy się zatem nieco dokładniej trzem niedawno wydanym tekstom, opowiadającym o relacjach polsko-żydowskich podczas wojny i po jej zakończeniu oraz o postrzeganiu Żydów przez Polaków, tekstom, które mogą wytrącić nauczycieli i uczniów ze światopoglądowej i aksjologicznej pewności oraz rozchwiać ideologiczną stabilność innych istniejących opowieści. Każdy z tych utworów skłania do zastanowienia, czym jest polskość, patriotyzm, obywatelskość, bohaterstwo i jak łatwo w sprzyjających okolicznościach dokonuje się zło i jak równie łatwo się je tymi okolicznościami usprawiedliwia.

\section{Sendlerowa. W ukryciu - o przywracaniu znaczenia słowu „boha- terstwo"}

Jednym z nich, dobrze przybliżającym realia, w jakich organizowano pomoc Żydom w okupowanej Polsce, jest książka Anny Bikont Sendlerowa. 
$W$ ukryciu. Trudno przecenić jej wartość edukacyjną. Autorce, na podstawie analizy bardzo wielu dokumentów źródłowych i rozmów, udało się przedstawić współczesnemu czytelnikowi okoliczności i atmosferę towarzyszące konspiracyjnej działalności poświęconej ratowaniu żydowskich współobywateli. Wspomnienie szmalcowników czyhających na łatwy zarobek, wskazywanie Żydów na warszawskich ulicach przez polskie dzieci i młodzież, działalność szantażystów domagających się zapłaty za milczenie o prawdziwej tożsamości ukrywających się, bardzo wysokie koszty związane z zakupem fałszywych dokumentów, opieką nad pozostawionymi dziećmi czy wynajęciem pokoju (znacznie wyższe dla Żydów niż dla Polaków) - to wspomnienia stale powracające $\mathrm{w}$ przywoływanych opowieściach ocalałych i pojawiające się w archiwach. Było to życie w poczuciu nieustannego zagrożenia, co trafnie wyrażają następujące słowa:

Po kwietniowym powstaniu 1943 roku nie było już dokąd wracać. Została tylko strona aryjska, gdzie ukrywający się Żydzi stawali się zwierzyną łowną. Nadszedł czas wielkiego polowania (Bikont 2017, 208).

Bikont nie umniejsza niebezpieczeństw czyhających na Polaków, którzy ukrywali Żydów. Potwierdza, że ewentualny donos oznaczał „śmierć nie tylko dla ukrywających się, ale (...) także śmierć tych, którzy pomagają" (Bikont 2017, 209). Przesłanka ta służy jednak przede wszystkim uświadomieniu, jak niewielkie szanse na przeżycie mieli ci, którzy na pomoc Polaków byli właściwie skazani. Niezwykłej bowiem odwagi, czasami ocierającej się o heroizm, wymagała postawa solidarności z Żydami. Urzeczywistnienie takiej postawy oznaczało zmierzenie się z tymi, którzy z różnych powodów stali obok, przyglądali się z dystansem, często motywowani strachem (co jest zupełnie zrozumiałe). Bikont burzy symetrię pielęgnowaną nierzadko w ideologicznej narracji, dzielącą społeczeństwo polskie na empatyczną, niosącą bezwarunkową pomoc większość, i wyjętą spod prawa, chciwą mniejszość kryminalistów, wykorzystującą słabych dla własnych interesów (reprezentowaną przez szmalcowników). Rzeczywistość była znacznie bardziej skomplikowana; los Żydów rzeczywiście leżał w polskich rękach, ale były to ręce największej grupy, na którą w symetrycznym układzie zabrakło miejsca, czyli obserwatorów:

Gdyby los ukrywających się w mieście ważył się między tymi, którzy pomagają, a szmalcownikami, nie byłoby aż tak tragicznie. Ale między nimi rozciąga się szara strefa i to ona powoduje, że szanse przeżycia są tak nikłe. W szarej strefie są ludzie w tramwajach i na ulicy, są mieszkańcy kamienicy, którzy wypatrują niearyjskich rysów i prowadzą o tym sąsiedzkie rozmowy, są wynajmujący mieszkania Żydom, którzy żądają bajońskich sum (Bikont 2017, 209).

Bikont robi wiele, by sprowadzić opisywaną przez siebie rzeczywistość do właściwych, faktycznych, wiarygodnych wymiarów. W tym celu wykorzystuje obrazowanie, służące przybliżeniu ówcześnie panujących nastrojów społecznych i najczęściej przyjmowanych postaw. Przypomina 
też okoliczności, w jakich narodził się - pielęgnowany do dzisiaj - mit o rzeszach szlachetnych Polaków ratujących powszechnie swych żydowskich braci i żydowskie siostry oraz jego dość wstydliwą i pewnie dlatego zwykle przemilczaną genealogię. Opowieść ta stanowiła bowiem „integralną część (...) antysemickiej propagandy" z 1967 i 1968 roku, heroizującej polski naród, zwłaszcza w osobach Sprawiedliwych wśród Narodów Świata i zarzucającej niewdzięczność, szczególnie środowiskom żydowskim, co najmniej sceptycznym wobec tego mitu ${ }^{5}$. Autorka książki o Sendlerowej postanowiła zweryfikować tak ukształtowaną narrację, badając również dokumenty źródłowe i poszukując twardych danych statystycznych o liczbie ocalałych Żydów. Relacja z tych poszukiwań jest przejmująca, bo ukazuje skalę Zagłady i potwierdza wyjątkowość innego scenariusza:

Gdy ma się w pamięci trzyipółmilionową żydowską społeczność żyjącą przed wojną w Polsce, już sama możliwość spisania na kilkudziesięciu stronach papieru maszynowego alfabetycznego wykazu ocalałych członków tej społeczności ${ }^{6}$ skłania do płaczu. Czytałam nazwiska ocalonych jak towarzyszącą im litanię zmarłych. Za każdym nazwiskiem stoi tak wiele osób z tej samej rodziny, miejscowości, tego samego getta, obozu, którym nie dane było znaleźć się w spisie (Bikont 2017, 396-397).

Oczywiście, że monstrualny rozmiar zbrodni dokonanej na Żydach obciąża nazistów i wynika z realizowanej przez nich polityki eksterminacyjnej. Uświadamia jednak równocześnie, jak trudno było się Żydom przed skutkami takiej polityki uchronić. Bez wątpienia miała ona również wpływ na postawy Polaków i raczej nie sprzyjała masowemu okazywaniu bohaterstwa przez społeczeństwo, również doświadczone okupacyjnymi represjami. Bikont z podejrzliwością traktuje zatem narrację o „uratowanych dzieciach":

Niestety bardziej realistyczne byłoby określenie: ratowane dzieci, bo wyprowadzone z getta musiały mieć wiele szczęścia, aby nie stracić życia po aryjskiej stronie (Bikont 2017, 409).

Dalej padają niewygodne wobec istniejących wyobrażeń zbiorowych pytania. Skoro udało się przeżyć tym, którzy zostali jakoś materialnie zabezpieczeni, by opłacić się szmalcownikom czy chciwym gospodarzom (a właśnie dzieci z raczej zamożnych rodzin zostały opisane przez autorkę książki jako ocalałe z Zagłady), to co z tymi, którzy takiego zabezpieczenia nie mieli? Ilu stało się ofiarą sąsiedzkich czy rówieśniczych (to kolejne tabu!) donosów czy ulicznych prowokacji? Czy ukrywający się na wsi i w mieście mieli takie same szanse? Czy podwyższało owe szanse wsparcie ze strony Żegoty? A może najlepszym schronieniem były klasztory, co potwierdzałyby dostępne dane? Ulokowanie żydowskiego dziecka w klasztorze wymagało

${ }^{5}$ Bikont podkreśla, że istotną rolę w zainicjowaniu tej historycznej narracji odegrał artykuł Józefa Goldkorna poświęcony konspiracyjnym działaniom Ireny Sendlerowej opublikowany w „Prawie i Życiu” w kwietniu 1967 roku (Bikont 2017, 311) obok tekstu Tadeusza Kura entuzjastycznie recenzującego książkę Władysława Bartoszewskiego i Zofii Lewinówny Ten jest z ojczyzny mojej opowiadającej o Polakach ratujących Żydów podczas II wojny światowej.

${ }^{6}$ Chodzi o Wykaz alfabetyczny Żydów polskich. 
wprawdzie starannie przygotowanej operacji logistycznej, ale chroniło przed licznym gronem obserwujących; być może dlatego były to miejsca najbezpieczniejsze. Nawet przybliżona liczba dzieci, którym udało się ujść z Zagłady, budzi poważny niepokój. Dane mówią bowiem o pięciu tysiącach spośród prawie miliona żydowskich dzieci, żyjących w przedwojennej Polsce. Jak zatem potraktować legendę, przypisującą Irenie Sendlerowej ocalenie połowy z owych pięciu tysięcy? Oznaczałoby to, że jeśli dzięki inicjatywie tylko jednej osoby i współpracującej z nią grupy ludzi było to możliwe, to jak te dane by wyglądały, gdyby takich osób w polskim społeczeństwie było więcej? Nie waha się sformułować takiego zadania - z pogranicza matematyki i etyki - Lea Balint:

jaki byłby to wstyd dla narodu polskiego, żeby jedna kobieta uratowała połowę wszystkich dzieci, które przeżyły? To by znaczyło, że wystarczyłoby dziesięć dzielnych kobiet, żeby uratować dwadzieścia pięć tysięcy dzieci? Sto Sendlerowych, by uratować ćwierć miliona? (Bikont 2017, 410).

Tło dramatycznych wydarzeń, które rozegrały się w okupowanej Polsce w latach 40. XX wieku, przybliżone przez Bikont, nie jest antypolską narracją, ale opowieścią o tym, jak niezwykle skomplikowanym, trudnym, ryzykownym przedsięwzięciem logistycznym i organizacyjnym była akcja niesienia pomocy Żydom. Historie ludzi zaangażowanych w tę pomoc składają się na historię działania ruchu obywatelskiego, przekraczającego różnice narodowe, światopoglądowe, polityczne, religijne, społeczne i odwołującego się do praw człowieka ${ }^{7}$ (zanim stały się one tematem zainteresowania na płaszczyźnie prawa międzynarodowego po zakończeniu II wojny światowej - zob. Sands, 2018). Dziwi to, że w szkolnej edukacji, która ma pokazywać wzorce i uczyć patriotyzmu, tak niewiele uwagi, poza kilkuzdaniową wzmianką w podręcznikach do historii, poświęca się właśnie choćby działalności Rady Pomocy Żydom Żegota. A jest o czym mówić. W wyjątkowo trudnych okolicznościach i ze świadomością podejmowanego ryzyka osobom zaangażowanym w ratowanie Żydów, których wcale nie było wiele, przyszło rozwiązywać bardzo konkretne problemy. Zajmowały się one między innymi wynajdywaniem odpowiednich mieszkań, wyszukiwaniem rodzin gotowych przyjąć Żydów pod swój dach, zdobywaniem odpowiednich dokumentów, organizowaniem konkretnej pomocy dla ukrywanych, zapewnianiem im opieki lekarskiej, zdobywaniem przepustek umożliwiających wejście na teren getta, trybem umieszczania żydowskich dzieci w sierocińcach, zapewnianiem im metryk chrztu, ubioru, odpowiedniej legendy biograficznej, systemem dostarczania pieniędzy umożliwiających

\footnotetext{
${ }^{7} \mathrm{~W}$ dość osobliwy sposób dokumentuje to odezwa napisana w 1942 roku przez Zofię Kossak-Szczucką, znaną ze swych antysemickich poglądów intelektualistkę, która wzywała w niej Polaków do niesienia pomocy Żydom. Pomoc tę uznała za czynny akt sprzeciwu wobec społecznej bierności nazywanej w tym tekście Piłatowym umywaniem rąk i do tego powszechnym. To na tyle interesujący dokument opisujący złożoność motywacji decydującej o zaangażowaniu się na rzecz tych, których darzy się wyjątkową niechęcią i uprzedzeniami, że warto go na lekcjach uczynić tematem dokładniejszej analizy, oczywiście z uwzględnieniem opisanego przez Bikont kontekstu (zob. Bikont 2017, 137).
} 
przetrwanie, awaryjnym i z reguły nagłym przenoszeniem zagrożonych donosami w inne bezpieczne dla nich miejsce. Było to nie tylko olbrzymie wyzwanie logistyczne (realizowane w sytuacji nieustającego zagrożenia zarówno ze strony Niemców, jak i części Polaków), ale też niezwykle poważne wyzwanie ekonomiczne (finansowe), a przede wszystkim wyzwanie dla odwagi cywilnej niosących pomoc:

Żegota nie tylko powstała późno, ale też z racji skromnych środków finansowych była w stanie objąć opieką zaledwie mały procent tych, którzy jej potrzebowali (Bikont 2017, 146).

Bikont przybliża skalę związanego z tym problemu. Pisze, że podopieczni otrzymywali od Żegoty 500 złotych, podczas gdy, jak obliczył Rubin Arnon, „jedzenie na kartki, które dawało 867 kcal dziennie, kosztowało miesięcznie 78 zł, tyle że Żydzi nie mieli kartek, co sprawiało, że ceny podstawowych artykułów szybowały do 416 zł miesięcznie, a gdyby liczyć «normalną» rację żywnościową (2400 kcal) - do 1150 zł. Do tego dochodził koszt wynajęcia łóżka czy pokoju - nawet do 150 zł dziennie - gdyż tak wyceniano ryzyko. Polak za 150 zł mógł wynająć pokój na miesiąc" (Bikont 2017, 147). To kolejne matematyczne ćwiczenie trafnie ilustruje, z jak trudnym zadaniem musieli mierzyć się ci, którzy w pomoc Żydom byli zaangażowani.

Opowieść Bikont to nie tylko historia Ireny Sendlerowej - postaci symbolicznej, na której skupiła się uwaga świata i która stała się swego rodzaju polskim alibi wobec zarzutów o niedostatek pomocy udzielanej Żydom, nie mówiąc o oskarżeniach o współpracę Polaków z Niemcami czy zwykłą obojętność. Walorem owej książki jest przybliżenie innych, równie interesujących postaci, które także zasługują na przypomnienie. Do grona takich bohaterek należy chociażby Stanisława Bussold (to jej swoje życie zawdzięcza Elżbieta Ficowska). Jaki zatem jest portret człowieka zasługującego na miano bohatera? Z pewnością nie jest to polski James Bond. To kobieta, która w 1942 roku, mając 56 lat, zdecydowała się pomóc w przeprowadzaniu Żydów z warszawskiego getta na stronę aryjską. Była już wówczas wdową po drugim mężu, miała syna, córkę i dwóch pasierbów (jeden z nich - Paweł Bussold, przedsiębiorca budowlany, wywiózł z getta sześciomiesięczną Elżbietę). Bussoldowa miała więc swoje własne życie, za sobą dwa nieudane małżeństwa i dość oziębłe relacje z własnymi dziećmi. Bikont podkreśla, że była osobą barwną, pełną temperamentu. Należała do drobnego ziemiaństwa, dbała o elegancki wygląd, do kościoła jeździła powozem, lubiła hazard, wyjeżdżała do Petersburga grać w ruletkę i pokera. Była też osobą wyjątkowo niezależną - ku zgorszeniu rodziny, mimo swego pochodzenia i dość wysokiego statusu majątkowego, postanowiła zostać położną. W czasie wojny zajmowała się odbieraniem porodów ukrywających się Żydówek, była też właścicielką i administratorką kamienicy na ulicy Kałuszyńskiej $5 \mathrm{w}$ Warszawie, gdzie przez pewien czas ukrywała wywiezioną z getta Elżbietę, którą potem przygarnęła i traktowała jak własną 
córkę. W świetle wcześniej zrekonstruowanych realiów można śmiało zaliczyć ją do grona bohaterek tamtych czasów. Na jej działalność składały się także takie czynności, jak - na przykład - znajdowanie miejsc, gdzie można ukryć żydowskie dziecko, sprawdzenie tych miejsc, opłacenie opieki, okłamywanie sąsiadów, by ukryć rzeczywiste pochodzenie dziecka. Umiała też zorganizować ucieczkę, gdy sama padła ofiarą donosu (ze strony Polaków).

Warto zatem, mówiąc o polskiej odwadze i poświęceniu okazywanym Żydom, pokazać je za pośrednictwem konkretnej postaci. Bohaterstwo zyskuje wówczas swoje imię i nazwisko, pochodzenie, słabości, przeszłość, charakter, a ponieważ okazuje się czymś wyjątkowym, to nie będzie zbyt wielkim obciążeniem dla pamięci współczesnych, jeśli owo imię i nazwisko zostanie przypomniane. W tym przypadku bohaterstwo nazywało się Stanisława Bussold.

\section{Drzazga jako dydaktyczna opowieść ostrzegawcza}

Inną perspektywę spojrzenia na relacje polsko-żydowskie podczas wojny można wyczytać z przerażającej książki Mirosława Tryczyka Drzazga. Kłamstwa silniejsze niż śmierć przypominającej okoliczności, w jakich w lipcu 1941 roku doszło do pogromów ludności żydowskiej, między innymi w Grajewie, Radziłowie i Wąsoszu. Autor nie stroni od szczegółowego przypomnienia tych tragicznych wydarzeń ukazanych w poetyce zbliżonej do opowiadań Tadeusza Borowskiego, takich jak Proszę państwa do gazu czy Ludzie, którzy szli. Intencją tego artykułu nie jest wskazanie konkretnych fragmentów wraz z sugestią dotyczącą tego, jak je wprowadzać na lekcje języka polskiego, ale namysł nad tym, jak ta, drobiazgowo zrekonstruowana, wstydliwie przemilczana, znacząco zniekształcana historia paradoksalnie otwiera możliwość jej edukacyjnego wykorzystania ${ }^{8}$.

Jedna z nich polega na potraktowaniu owej reporterskiej, dobrze udokumentowanej, opowieści jako ostrzeżenia przed możliwymi skutkami podgrzewania nacjonalistycznych i ksenofobicznych nastrojów oraz przyzwolenia na antysemicką propagandę (czy jakąkolwiek inną wykluczającą mniejszość i ją stygmatyzującą). Wielu rozmówców Tryczyka właśnie o takiej nagonce na Żydów wspomina, szczególnie akcentując, że przypadała on już na lata 30. XX wieku ${ }^{9}$. Była to akcja starannie koordynowana i organizowana przez środowisko Obozu Wielkiej Polski, Obozu Narodowo-Radykalnego i członków przedwojennego Stronnictwa Narodowego. Tak agresywnie manifestowany nacjonalizm spotkał się z akceptacją przynajmniej części

\footnotetext{
${ }^{8}$ Warto w szkolnej edukacji zastanowić się nad wykorzystaniem potencjału edukacyjnego, wynikającego z wyzyskania intertekstualnych relacji między utworami omawianymi w tym artykule, w tym także tekstem Tryczyka, a opowiadaniem Idy Fink Drzazga.

${ }_{9}^{\mathrm{O}}$ wpływie takiej nagonki i propagandy na tragiczny los pierwszego prezydenta II Rzeczpospolitej zob.: Brykczyński P., 2017, Gotowi na przemoc. Mord, antysemityzm i demokracja w międzywojennej Polsce, Warszawa. O tym wstydliwym wydarzeniu w historii polskiej państwowości raczej się nie przypomina zbyt często zarówno w dyskursie publicznym, jak i w szkole. Zob. też: Nowak M.J., 2019, Narutowicz. Niewiadomski. Biografie równoległe, Warszawa.
} 
polskiej ludności zamieszkującej wspomniane miejscowości, w tym także młodzieży, oferując im rodzaj ideologicznego usprawiedliwienia.

Godny uwagi i w dodatku bardzo niepokojący jest również inny wniosek nasuwający się po lekturze książki Tryczyka. Okazuje się, że nacjonaliści nie tylko ofiarowywali ideologiczne rozgrzeszenie swoim stronnikom, ale sami otrzymywali duchowe i retoryczne wsparcie ze strony niektórych księży katolickich. W świetle tego, co wydarzyło się zatem w lipcu 1941 roku, tę historię można potraktować jako poważne ostrzeżenie przed instrumentalnym traktowaniem religii, wykorzystywanej jako narzędzie tożsamościowej i etnicznej autoidentyfikacji konstruowanej w konfrontacji wobec innych, uznawanych za gorszych, obcych, wrogów. To ważna lekcja pokazująca, że możliwa jest nie tylko religijność, którą łączą ścisłe relacje z polityką, ale też religijność z gruntu antychrześcijańska, mimo że swoje racje uzasadnia odwołaniami do wartości chrześcijańskich.

W Drzazdze przedstawione zostały również warunki, w jakich dochodzi do erupcji nienawiści i przemocy. Już sam opis przestrzeni na przykład Radziłowa, który Tryczyk przywołuje za pośrednictwem swego rozmówcy - Jana Skrodzkiego - przybliża obraz relacji polsko-żydowskich ukształtowany przez nieufność, zawiść, rywalizację:

Żydzi zajmowali się handlem i rzemiosłem. Polacy im zazdrościli. Mój ojciec prowadził zakład krawiecki. Miał czeladników, wyłącznie Polaków. A jak wybudował dom przy ulicy Pięknej, to na ścianie szczytowej domu, od strony rynku, gdzie było jedno okno na piętrze, napisał: „Pracownia krawiecka chrześcijańska”. Bo były w Radziłowie cztery pracownie, z czego trzy prowadzone przez Żydów. I oni się zwalczali, mój ojciec i Żydzi. A na dole, na tej ścianie domu od ulicy Pięknej, było napisane: „Piekarnia chrześcijańska”, prowadził ją Polak, pan Odyniec z Wizny. Przeciwko Żydom. W każdy czwartek był targ w Radziłowie i na ten targ przyjeżdżali z okolicznych wiosek chłopi na zakupy, i większość stoisk handlowych to były stoiska żydowskie... A rynek był piękny w Radziłowie, czworokątny... i też wszystkie mieszkania, domy, sklepy przy rynku były żydowskie. W bocznych uliczkach, które dochodziły do rynku, działały pojedyncze sklepiki polskie, ale było ich mało. Pamiętam dwa (...). A Żydzi byli bogaci... Mieli na szkoły, a nawet na studia dla swoich dzieci. Złoto! Złoto się przewijało, wszyscy gadali o żydowskim złocie (Tryczyk 2020, 24-25).

W tę przestrzeń konfrontacji i niechęci w 1939 roku wkroczyła wielka historia. Część polskich mieszkańców zaangażowała się w antykomunistyczną partyzancką działalność wymierzoną przeciw wojskom sowieckim, co spotkało się z represjami ze strony NKWD. Gdy w czerwcu 1941 roku ruszyła ofensywa niemiecka na ZSRR, tereny te przeszły w ręce administracji hitlerowskiej. Historyczny huragan do końca zniszczył i tak już bardzo słabe relacje między Polakami i Żydami. Dwa niezwykle ekspansywne systemy totalitarne przeobraziły nieodwracalnie system polityczny, gospodarczy, społeczny całej przedwojennej Europy, która nie potrafiła temu w żaden sposób zapobiec. Gdy zatem dotarły do małych miejscowości, jak Radziłów, Wąsosz, Grajewo, Szczuczyn czy Jedwabne, powstały sprzyjające 
warunki do tego, by sięgnąć po przemoc już nie tylko wymierzoną w pojedynczych ludzi czy pojedyncze rodziny, ale w całą zamieszkującą je społeczność żydowską. Pozbawiona ochrony prawnej i instytucjonalnej ${ }^{10}$, oskarżona o sprzyjanie Sowietom, ciągle dysponująca majątkiem, kulturowo i religijnie odmienna, stała się łatwym celem dla tych, którzy upatrywali w niej winowajców swojej trudnej sytuacji.

Ten wymiar opowieści Tryczyka ma istotną wartość edukacyjną. Pokazuje z jednej strony, że państwo z całym swoim systemem ochrony, zapewniającym teoretycznie bezpieczeństwo wszystkim swoim obywatelom, ma spory kłopot z zapobieganiem ekspansji myślenia ksenofobicznego i nacjonalistycznego (warto się zastanowić nad skutkami, gdy w dodatku państwo jeszcze takie myślenie wspiera lub usprawiedliwia), chętnie sięgającego po praktyki dyskryminacyjne. Z drugiej strony ostrzega, że w sytuacji kryzysowej, gdy zmiecione zostają wszelkie struktury państwowe i zastępuje się je tymczasową administracją okupacyjną, wyjątkowo łatwo o przemoc, dotychczas trzymaną w ryzach, wymierzoną w grupę, wobec której od dawna buduje się atmosferę wrogości. Tryczyk pokazuje, jak trudno się potem owej przemocy przeciwstawić i ją powstrzymać (przecież o udział w pogromach nie byli oskarżeni wszyscy mieszkańcy; to konkretni sprawcy nadawali rytm podjętym działaniom, a po wojnie uważali się za depozytariuszy jedynie słusznej prawdy o polskości, nakazując innym milczenie o zbrodni i kształtując narrację o przeszłości w taki sposób, by zdjąć z siebie i swoich wspólników odpowiedzialność za to, co się stało).

Wreszcie Drzazgę można także analizować jako opowieść o bardzo groźnym rozumieniu polskości. Rozmowy Tryczyka z mieszkańcami miejscowości pogromowych, spotkania z potomkami osób zamieszanych w te tragiczne wydarzenia, z jeszcze żyjącymi ich świadkami, jak i z zainteresowanymi dotarciem do prawdy lub/i jej upamiętnieniem, są świadectwem, że polskość może być kategorią wykluczającą i dyskryminującą, zdejmującą odpowiedzialność za popełnione przez Polaków zło w imię jakiejś wyobrażonej solidarności zbiorowej i dobra wspólnego, fałszującą prawdę, zniekształcającą rzeczywistość, odrzucającą jakiekolwiek oskarżenia, nawet gdy istnieją dowody dokonanej zbrodni. Ale część z wymienionych osób jest gotowa się z tą trudną tematyką zmierzyć, nawet jeśli przeszłość rzuca cień na ich rodzinę czy miejscowość, z której pochodzą. W ich rozumieniu polskość wymaga więc dopełnienia innymi wartościami - empatią, szacunkiem, intelektualną uczciwością, krytyczną refleksją, a więc de facto wartościami obywatelskimi.

Kimś takim jest chociażby pochodząca z Radziłowa Anna, jedna z rozmówczyń Tryczyka, która w 2016 roku postanowiła napisać pracę magisterską o mordzie dokonanym w jej rodzinnej miejscowości (ku konsternacji

\footnotetext{
${ }^{10} \mathrm{Na}$ związek między nagłym lub stopniowym zdejmowaniem ochrony prawnej nad Żydami, dokonywaną za pomocą rozwiązań administracyjnych inicjowanych przez III Rzeszę, a Zagładą zob.: Snyder T., 2015, Czarna ziemia: holocaust jako ostrzeżenie, Kraków. Przestrzega w niej współczesnych przed powtarzalnością tego schematu, który przynosi wstrząsające skutki.
} 
i zakłopotaniu swojego promotora). Co ciekawe, dowiedziała się o popełnionej zbrodni, mając 14 lat, podczas gimnazjalnej wycieczki, ale poznała to zdarzenie w zupełnie innej wersji ${ }^{11}$ niż ta, którą udało się jej odkryć, analizując akta tej sprawy. Natomiast o rzeczywistych sprawcach mordu usłyszała najpierw od swojej matki (Anna miała wówczas 19 lat). Interesująco tłumaczy swoje motywacje:

Chcę mówić prawdę o zbrodni w Radziłowie, bo jak ludzie przeczytają moją historię, historię moich wujków, to może inaczej spojrzą na to, co się stało? Żyje tam już kolejne pokolenie i ono nie odpowiada bezpośrednio za to, co się stało. Uważam też, że jest tam wiele osób z rodzin, które mordowały, i że te osoby chciałyby o tym porozmawiać, ale nie mają motywacji (Tryczyk 2020, 36).

Warto przyjrzeć się tej galerii osób gotowych poznać prawdę o tamtych tragicznych wydarzeniach, tym bardziej że są wśród nich ludzie młodzi, potrafiący myśleć samodzielnie, krytycznie i na własną rękę dociekać tego, co się wydarzyło. Nie zadowalają się powierzchownym szkolnym i rodzinnym przekazem, a nawet buntują się wobec niepojętej dla nich zmowy milczenia. To chyba zła wiadomość dla populistów, narzucających nacjonalistyczny sposób mówienia i myślenia o polskości. Przywracanie prawdy i jej przypominanie wcale nie jest skazane na porażkę, a obywatelski model postrzegania narodowej tożsamości potrafi zmierzyć się z tematami należącymi do sfery wspólnotowego oraz edukacyjnego tabu ${ }^{12}$.

\section{Lekcje obywatelskiego sceptycyzmu - Marcin Kącki Białystok. Biała siła, czarna pamięć}

Interesującą perspektywę podejmowania refleksji na temat przemilczeń w relacjach polsko-żydowskich proponuje również Marcin Kącki. Jego reporterska opowieść o poszukiwaniu śladów obecności Żydów w Białymstoku i na Podlasiu, i o trudnym procesie przywracania o nich pamięci, pokazuje bariery utrudniające rzetelną edukację na ten temat. Autor musi się nieustannie przedzierać przez frazesy, slogany, półprawdy, kłamstwa, plotki, ideologiczne manifesty, wyolbrzymienia i wiele innych językowych sposobów chroniących przed prawdą o całkiem niedawnej historii. Jego zadanie jest tym bardziej skomplikowane, że z przestrzeni

\footnotetext{
${ }^{11} \mathrm{~W}$ miejscu stodoły spalonej w lipcu 1942 roku pod pomnikiem znajdował się następujący tekst: „W sierpniu 1941 roku faszyści zamordowali 800 osób narodowości żydowskiej, z tych 500 osób spalili żywcem w stodole. Cześć ich pamięci”(Tryczyk 2020, 34).

${ }_{12}$ Także z tym, który dotyczy sposobu przejmowania przez Polaków żydowskiego majątku podczas wojny i po jej zakończeniu, ale też przerażającej praktyki polegającej na przekopywaniu ziemi ze szczątkami pomordowanych Żydów w byłych obozach zagłady w poszukiwaniu kosztowności. To kolejny przemilczany temat, który ujrzał światło dzienne - zob.: Reszka P.P., 2019, Płuczki. Poszukiwacze żydowskiego złota, Warszawa. Także ta opowieść, mimo swojej grozy, zawiera bardzo interesujący potencjał edukacyjny. Jeden z rozmówców reportażysty, Michał Bilewicz, zwraca na przykład uwagę na to, by mówiąc o Holokauście, uczyć nie tylko o śmierci, ale i o wcześniejszym życiu ofiar, gdyż to je uczłowiecza (Reszka 2019, 56). Osadza też wstrząsającą opowieść Reszki w szerszym, antropologicznym i psychologicznym kontekście, stwierdzając, iż świadkowie korzystają ze zbrodni ludobójstwa wszędzie, gdzie do niej doszło, a więc nie tylko w Bełżcu, ale i w Rwandzie, Srebrenicy, Armenii. Przybliża również mechanizm oswajania przez język praktyki rabowania zamordowanych w obozach zagłady - na tak groźne wykorzystywanie języka raczej nie zwraca się uwagi w szkolnej edukacji. To tylko wybrane przykłady ilustrujące, że warto się owej książce przyjrzeć.
} 
publicznej usunięto większość śladów pamięci, umożliwiających zrekonstruowanie przeszłości, a zrobiono to tak skutecznie, że mieszkańcy są zupełnie nieświadomi, iż Białystok przed II wojną światową był miastem żydowskim. Książka zawiera opis faktów potwierdzających zarówno realia okupacyjne przybliżone w opowieści Bikont o Sendlerowej, jak i bohaterstwo zwykłych ludzi, którzy pomagali ukrywać Żydów (narażając się na sąsiedzkie donosy i zmagając się z szmalcownikami), ale też poświadczenie pogromów dokonanych na Żydach przez ich polskich sąsiadów po wkroczeniu na Podlasie wojsk niemieckich w 1941 roku (cytowany przez Kąckiego historyk - Andrzej Żbikowski - naliczył 29 miejscowości, gdzie do nich doszło - Kącki 2015, 91).

W kontekście rozważań nad edukacyjnym sposobem mówienia o przemilczeniach istotne są jednak pytania, jakie się nasuwają po lekturze opowieści o współczesnym, dużym polskim mieście i trawiącej go amnezji historyczno-kulturowej. Jak ukazywać skomplikowaną przeszłość miast, miasteczek i wsi, gdzie zamieszkiwali Żydzi? Jak realizować edukację regionalną w sytuacji, gdy fałszuje się przeszłość regionu, wymazuje z niego istotny element lokalnej tożsamości, tworząc w jej miejsce tożsamość marketingową, przyciągającą turystów? Z jakich powodów warto, można, trzeba podejmować nawet najtrudniejsze tematy, wytrącające $\mathrm{z}$ etycznego komfortu?

Być może konieczne są lekcje obywatelskiego sceptycyzmu, polegające na odkrywaniu śladów żydowskiej obecności przez demaskowanie fałszu tkwiącego $\mathrm{w}$ oficjalnych i powszechnych narracjach. Tym zajmuje się na przykład jedna z rozmówczyń Kąckiego - Katarzyna Sztop-Rutkowska. Nie tylko przedstawia liczne dowody, że Białystok jest miastem bez pamięci (Kącki 2015, 52), pomijającym fakty świadczące o tym, jak znacząco Żydzi tworzyli jego historię do lat 40. XX wieku, ale odkrywa również, że na nowo konstruuje ono swoją tożsamość i przeszłość, przedstawiając się jako miasto wielokulturowe, otwarte na inność. Przeprowadzone przez nią badania dowiodły jednak, że zdecydowana większość jego mieszkańców wierzy w przeszłość, która nigdy nie istniała, w stworzoną przez obiegowe opinie, niedostatek wiedzy i świadome przemilczenia tradycję kulturową czasami rozmijającą się z prawdą. Nawet na stronach internetowych Urzędu Miejskiego wskazuje elementy manipulacji i niedopowiedzeń sprzyjające owej fikcyjnej tradycji:

Czytam. Historia Żydów, których okresami było w mieście nawet 75 procent, została tam umieszczona w podrozdziale poświęconym „mniejszościom”. Są też przemilczenia. W 1919 roku władze polskie włączyły do Białegostoku okoliczne wsie, by w wyborach samorządowych pozbawić Żydów większości w radzie miasta. Na stronach urzędu: „Wszyscy mieszkańcy międzywojennego Białegostoku mieli równe prawa wyborcze, zarówno $\mathrm{w}$ wyborach do władz samorządowych, jak i polskiego parlamentu. W kalendarium "historii miasta” nie ma słowa o Żydach. Nawet okres wojny, gdy ludność żydowska wyparowała, opisuje zdanie: „1939-1944 - II wojna 
światowa - represje wobec ludności i zniszczenie 75 proc. białostockiej zabudowy (Kącki 2015, 56). ${ }^{13}$

Książka Kąckiego podsuwa jeszcze inną niż dotąd opisane strategię edukacyjną, wartą realizacji na lekcjach obywatelskiego sceptycyzmu. Polegałaby ona na dokładnej analizie języka nienawiści, zakłamania, fałszu, dyskryminacji, stygmatyzacji, refleksji nad przyczynami jego stosowania, sposobami jego uprawomocniania, a przede wszystkim skutkami, często bardzo konkretnymi (takimi jak akty wandalizmu, groźby, ujawnianie danych osobowych osób uznanych przez środowiska ekstremistyczne za swoich wrogów, a nawet pobicia czy podpalenia). Mechanizm ten można przybliżyć, analizując bardzo konkretne sytuacje. Jedną z nich opisuje Kącki w rozdziale Klatka, opowiadającym o edukacyjnej działalności białostockiej polonistki Anny Janiny Klozy, która postanowiła przedstawić, zwłaszcza młodym ludziom, tragiczny los Żydów - zarówno tych, którzy zginęli w czasie Holokaustu, jak i tych, którzy cudownie uszli z życiem.

Zwieńczeniem jej aktywności było przedstawienie Nie chce pamiętać. Nie mogę zapomnieć, powstałe na podstawie wspomnień Merki Szewach, byłej mieszkanki Białegostoku, opowiadające o dramacie Żydów w czasach Zagłady. Wspomniana nauczycielka czynnie brała udział również w inicjatywach antyrasistowskich, w akcjach przypominających o żydowskiej części białostockiej tożsamości i organizowała spotkania ze świadkami tragicznej historii z pierwszej połowy lat 40 . XX wieku. Te lekcje obywatelskiego myślenia zostały wprawdzie docenione przez władze państwowe, a także przez tak ważne osoby, jak Marek Edelman i Wisława Szymborska, ale przede wszystkim spotkały się z wyjątkowo agresywną reakcją ze strony środowisk nacjonalistycznych. Kloza doświadczyła na sobie, że przywracanie pamięci o skomplikowanych relacjach polsko-żydowskich ma wysoką cenę. Nie tylko ujawniono na rasistowskim portalu jej imię, nazwisko, mail, adres i numer telefonu, ale grożono jej, że podzieli los zamordowanych Żydów. Na jej skrzynce pocztowej namalowano swastykę, a na ścianach prowadzących do jej mieszkania (znajdującego się na osiedlu strzeżonym!) ktoś wyrżnął szubienice z gwiazdami Dawida (Kącki 2015, 126-128). Także takie historie warto omawiać na lekcjach - pozwalają bowiem zastanowić się nad tym, czym jest odwaga cywilna (obywatelska) dzisiaj i jakie łączą

\footnotetext{
${ }^{13} \mathrm{Na}$ aktualnych stronach Urzędu Miasta w Białymstoku oraz w przewodniku, który można stamtąd pobrać, są wzmianki o ludności żydowskiej zamieszkującej to miasto, ale trudno zauważyć, by przywiązywano do tego jakąś większą wagę i przypisywano temu dziedzictwu jakieś większe znaczenie. Należy jednak zaznaczyć, że w opisie Szlaku esperanto i wielu kultur zachęca się turystów do zwiedzenia obiektów przypominających o żydowskich śladach obecności, przede wszystkimi związanych z Ludwikiem Zamenhoffem i jego działalnością. Jest tam także wzmianka o Szkole Żydowskiej Tarbut (bez komentarza wyjaśniającego, czym się dokładniej w niej zajmowano i jakie miała znaczenie), o budynku dawnej synagogi odremontowanej w 1989 roku, o targowisku Rynek Sienny (znajdującym się w dawnej dzielnicy żydowskiej - Chanajce) oraz o pomniku poświęconym synagodze w dawnej dzielnicy żydowskiej Szulhof, upamiętniającym również śmierć spalonych w niej przez Niemców ok. 700 Żydów (27 czerwca 1941 roku). Analiza tych i innych informacji dotyczących żydowskich mieszkańców miasta w kontekście innych umieszczonych tam materiałów skłania mimo wszystko do potwierdzenia tezy Sztop-Rutkowskiej, że podporządkowane są one narracji eksponującej wielokulturowość Białegostoku jako rdzeń tożsamości tego miasta. Zob. https://www.bialystok. pl/pl/dla turystow/turystyczne praktyczne info/ (dostęp: 20.02.2021).
} 
ją relacje z odwagą okazywaną choćby przez znanych z imienia i nazwiska, ale też anonimowych, sprawiedliwych wśród narodów świata ${ }^{14}$.

\section{Lektura egzystencjalna jako lektura proobywatelska}

Poruszana w tym artykule tematyka oraz przywołane teksty potwierdzają, że czytanie to niebezpieczna praktyka kulturowa. Może bowiem naruszać podstawy tego, co wydaje się od dawna ustalone, niezmienne, pewne, podane do wiadomości, „raz na zawsze” wyjaśnione. Polega na podejrzliwym traktowaniu oficjalnych narracji, opisujących świat dawniej i dziś, na poszukiwaniu w nich pęknięć, sprzeczności, niejasności, uproszczeń, niedopowiedzeń, a nawet fałszu. Stale narusza fundamenty, na których zbudowane jest nasze postrzeganie świata. Trafnie ujmuje to Michał Paweł Markowski: „Czytanie jako negacja tego, co dane: jest to być może najlepsza definicja, jaką można sformułować” (Markowski 2015, 54). Badacz, powołując się na Pessoę, kategorycznie sprzeciwia się przypisywaniu lekturze funkcji utwierdzania nas we własnej tożsamości i poczuciu przynależności do danej wspólnoty, na potwierdzaniu tego, co już o rzeczywistości wiemy, jak o niej myślimy i jak ją wartościujemy (Markowski 2015, $55)^{15}$. Z niezgody na taki sposób pojmowania czytania wyrasta egzystencjalny model lektury, uwrażliwiony na „anomalie, konkretności, wyjątki, różnice, szczegóły, pojedyncze występy jakiegoś aktora” (Markowski 2015, 62) i pozwalający „przesunąć swój punkt widzenia, by spojrzeć na siebie innymi oczami" (Markowski 2015, 57).

Rozważania te nabierają szczególnego znaczenia w kontekście refleksji nad relacjami polsko-żydowskimi, podejmowanej aktualnie na lekcjach. Taki tryb myślenia i lektury pozwala dostrzec, że polskość - podobnie jak bohaterstwo - ma różne oblicza, a nie jedno, i że wartość literatury polega nie tylko na stymulowaniu katastrofy, jak pisał Ryszard Koziołek w eseju Humanista sygnalista (Koziołek 2019), ale też jej opisaniu, zwłaszcza kiedy do niej doszło, i na diagnozowaniu warunków, które jej sprzyjają ${ }^{16}$. Jednak czytanie egzystencjalne, o czym należy pamiętać, ma swoją cenę. Wymaga

\footnotetext{
${ }^{14} \mathrm{O}$ podobnych problemach z pamięcią i o trudnościach z przypominaniem tego, co przemilczane, o języku agresji i fałszowania przeszłości, o odwadze podejmowania trudnych tematów oraz kosztach, jakie się za to ponosi, Marcin Kącki opowiada również w książce Oświęcim. Czarna zima (Kraków 2020). Warto po nią sięgnąć, gdyż zawiera sporo inspirujących refleksji na temat tego, jak i po co rozmawiać z młodymi współczesnymi polskimi uczniami i uczennicami o relacjach polsko-żydowskich oraz jak w ramach edukacji szkolnej mierzyć się z przejawami dyskryminacji, nienawiści rasowej i etnicznej, agresywnym nacjonalizmem czy ksenofobią. Omówienie szczegółowe tych kwestii wymagałaby napisania dłuższego tekstu analitycznego, na co w tym artykule nie ma już miejsca.

${ }^{15}$ Z podobnej filozofii myślenia wyrosła koncepcja Ludwika Zamenhofa, gdy zaproponował nowy uniwersalny język - esperanto, umożliwiający porozumienie między ludźmi i kształtowanie przyjaznych między nimi relacji wykraczających poza etniczne, religijne, kulturowe antagonizmy i przynależności. Jak trudno taką koncepcję przeforsować i upamiętnić, zwłaszcza w obliczu nacjonalistycznej narracji o przeszłości i współczesności, Marcin Kącki opisuje w rozdziale Babel (Kącki 2015, 72-83). Tym zagadnieniom warto również przyjrzeć na lekcjach języka polskiego (zob. też rozdział Zamiast wstępu we wspomnianej książce Kąckiego).

${ }^{16}$ Cenne w tym kontekście może być wykorzystanie edukacyjnego potencjału tkwiącego w publikacjach: Szuchta R., Trojański P., 2012, Zrozumieć Holokaust: książka pomocnicza do nauczania o zagładzie Żydów, Warszawa - Oświęcim czy Wybór źródeł do nauczania o Zagładzie Żydów na okupowanych ziemiach polskich, 2010, Szuchta R., Młynarczyk W., Skibińska A. (oprac.), Warszawa.
} 
odwagi mówienia o sprawach, które są przemilczane i zastępowane narracją konstruującą afirmatywny model tożsamości (agresywną wobec jakichkolwiek przejawów sceptycyzmu). Wydaje się jednak, że młodzi ludzie, mający dzisiaj kilkanaście lat, żyjący w połączonym, przynajmniej technologicznie, ekskluzywnym świecie, uczący się w demokratycznym europejskim dużym państwie, stykający się z innością na każdym niemal kroku, nieprzywiązujący do historii (przeszłości) znaczącej wagi, nieobciążeni żadną winą ani traumą za winy przodków, zasługują na dojrzałe, przemyślane lekcje obywatelskiego sceptycyzmu uodparniające być może na wirus ksenofobii, populizmu czy nacjonalizmu (zob. Koc 2018). Warto wraz z nimi odkrywać, że za każdym bohaterstwem stoi czyjeś tchórzostwo i bierność, za bezinteresownością - chciwość, za poszanowaniem praw każdego człowieka - pokusa wykluczania i stygmatyzacji, za dążeniem do odkrywania prawdy - potrzeba jej fałszowania, za szacunkiem do wolności słowa i myślenia - chęć ich poskramiania.

\section{Bibliografia:}

Bikont Anna, 2017, Sendlerowa. W ukryciu, Wołowiec.

Brykczyński Paweł, 2017, Gotowi na przemoc. Mord, antysemityzm i demokracja w międzywojennej Polsce, Sutowski M. (przeł.), Warszawa.

Kania Agnieszka, 2017, Lekcja (nie)obecności. Dziedzictwo polsko-żydowskie w edukacji polonistycznej, Kraków.

Karolak Sylwia, 2014, Doświadczenie Zagłady w literaturze polskiej 1947-1991: kanon, który nie powstat, Poznań.

Kącki Marcin, 2015, Białystok. Biała siła, czarna pamięć, Wołowiec.

Kącki Marcin, 2020, Oświęcim. Czarna zima, Kraków.

Koc Krzysztof, 2018, Lekcje myślenia (obywatelskiego). Edukacja polonistyczna wobec współczesnego świata, Poznań.

Koziołek Ryszard, 2019, Wiele tytułów, Wołowiec.

Krastew Iwan, 2013, Demokracja nieufnych, Eseje polityczne, Sutowski M. (przeł.), Warszawa.

Markowski Michał Paweł, 2015, Kiwka, Kraków - Budapeszt.

Reszka Paweł Piotr, 2019, Płuczki. Poszukiwacze żydowskiego złota, Warszawa.

Sands Philippe Joseph, 2018, Powrót do Lwowa: o genezie „ludobójstwa” $i$ „zbrodni przeciw ludzkości”, Soszyński J. (przeł.), Warszawa.

Snyder Timothy, 2015, Czarna ziemia: holokaust jako ostrzė̇enie, Pietrzyk B. (przeł.), Kraków.

Tryczyk Mirosław, 2020, Drzazga. Kłamstwa silniejsze niż śmierć [e-book], Kraków.

Wójcik-Dudek Małgorzata, 2016, W(y)czytać Zagładę. Praktyki postpamięci $w$ polskiej literaturze XXI wieku dla dzieci i młodzieży, Katowice. 
Zagłada w „Medalionach” Zofii Nałkowskiej. Tekst i konteksty, 2016, Żukowski T. (red.), Warszawa.

\section{O Autorze:}

Krzysztof Koc - profesor UAM w Pracowni Innowacji Dydaktycznych (w Instytucie Filologii Polskiej w Poznaniu), sekretarz naukowego czasopisma metodycznego „Polonistyka. Innowacje”. Jego zainteresowania badawcze koncentrują się wokół reportażu oraz szkolnej edukacji humanistycznej podejmującej dialog ze współczesnością. Opublikował dwie książki: Czytanie świata. Reportaże Ryszarda Kapuścińskiego w edukacji polonistycznej (Poznań 2007) i Lekcje myślenia (obywatelskiego). Edukacja polonistyczna wobec współczesnego świata (Poznań 2018). Jest również współautorem podręcznika akademickiego dydaktyki kształcenia polonistycznego Innowacje i metody. W kręgu teorii i praktyki (Poznań 2011). Przygotowuje do druku nową książkę pt. Netfliksowy humanista. 
